
\title{
CIÊNCIANAATURA
}

\section{Mapeamento da fragilidade ambiental na bacia hidrográfica do reservatório da UHE Caçu - Goiás}

Mappingoftheenvironmentalfragility in thehydrographicbasinoftheHydroelectricPlantreservoir in Caçu - Goiás

Celso de Carvalho Braga ${ }^{1}$, João Batista Pereira Cabral ${ }^{2}$, Simone Marques Faria Lopes ${ }^{3}$ e Daiane Ferreira Batista ${ }^{4}$

${ }^{1}$ Docente do IFG, Doutorando em Geografia pela Universidade Federal de Goiás/Jataí, Brasil ccarvalhobraga@gmail.com

${ }^{2}$ Docente da Universidade Federal de Goiás, Orientador no Programa de Pós-Graduação em Geografia - Regional Jataí- GO, Brasil

jbcabral2000@yahoo.com.br

\author{
${ }^{3}$ Doutora em Geografia pelo Instituto de Estudos Socioambientais IESA, Jataí - GO, Brasil \\ simoneufg@yahoo.com.br
}

${ }^{4}$ Doutoranda em Geografia pela Universidade Federal de Goiás, Regional Jataí, Jataí - GO, Brasil daiane-fb@hotmail.com.br

\begin{abstract}
Resumo
A fragilidade do ambiente pode ser vista como uma proposta de investigação, cujo principio básico é definir os diferentes níveis de fragilidade dos ambientes naturais e dos ambientes alterados pelas atividades antrópicas. Este estudo teve por objetivo avaliar os niveis de Fragilidade Ambiental na bacia hidrográfica do reservatório da Usina Hidrelétrica (UHE) Caçu em dois periodos distintos: antes da formação do reservatório (2009) e após a formação do reservatório (2014). A metodologia utilizada seguiu a proposta de Ross (1994). Os parâmetros avaliados foram: solos, declividade; erosividade e uso da terra. Os resultados encontrados mostram que a bacia analisada tinha o predomínio da classe de baixa fragilidade, que ocupava 74,88\% da área da bacia em 2009 e 77,52\% em 2014, a classe de média fragilidade, em 2009, ocupava 20,79\% da área, e em 2014 passou a ocupar 21,12\%. A alta fragilidade diminuiu de 4,34\% em 2009 para 1,36\% em 2014, devido às mudanças no uso do solo da bacia. Deve-se destacar que aproximadamente $25 \%$ da área da bacia classificam-se entre média e alta fragilidade, demostrando a necessidade de cuidados especiais e utilização de práticas conservacionista em relação ao uso da terra.
\end{abstract}

Palavras-chave: Uso da terra. Solos. Declividade. Erosividade.

\section{Abstract}

The fragility of the environment can be seen as a research proposal, whose basic principle is to define the different levels of fragility of natural environments and environments already altered by anthropic activities. This study aimed to evaluate the Environmental Fragility levels in the hydrographic basin of the Hydroelectric Plant reservoir in Caçu (UHE), in two distinct periods: before the formation of the reservoir (2009) and after the formation of the reservoir (2014). The methodology used followed the pattern of Ross (1994). The estimated parameters were: soils, declivity; erosivity and land use. The results show that the basin analyzed has a predominance of low fragility class, which occupied $74.88 \%$ of the basin area in 2009, and 77.52\% in 2014; the medium fragility class, in 2009, used to occupy 20.79\% of the area, and in 2014 it occupied $21.12 \%$. The high fragility class decreased from $4.34 \%$ in 2009 to $1.36 \%$ in 2014, due to changes in the basin soil use. It should be noted that approximately $25 \%$ of the basin area is classified as medium to high fragility, demonstrating the need for special care and use of conservationist practices related to the land use.

Keywords: Land use. Soils. Declivity. Erosivity. 


\section{Introdução}

Fragilidade ambiental consiste em organizar em diferentes níveis hierárquicos o zoneamento de um determinado território, com o objetivo de representar os graus de fragilidade do ambiente. Essa organização permite definir quais as áreas são mais susceptíveis e que apresentam maior potencial para degradação ambiental. Então, por fragilidade ambiental entende-se a potencialidade da desestabilização do equilíbrio dinâmico existente no ambiente.

Ross (1994) introduziu o conceito de fragilidade ambiental no Brasil como sendo a desestabilização do equilíbrio em ambientes antropizados, pois o mesmo entende que, em ambientes naturais, existe um equilíbrio dinâmico até a intervenção do homem no meio ambiente, quando explora os recursos naturais. A fragilidade ambiental pode ser ocasionada por processos naturais, causados pelos fatores endogenéticos e exogenéticos, ou a partir dos processos antrópicos, ocasionados pela ação do homem a partir dos modelos de uso da terra.

Segundo Ross (1994) e Spörl (2007), existem dois tipos de fragilidade: a fragilidade ambiental potencial, que se entende como áreas em que não existe interferência humana, causando situação de desequilíbrio do meio, onde predomina somente o intemperismo físico-químico como agentes naturais de modificação e a fragilidade ambiental emergente, relacionada ao modelo de uso da terra e recursos naturais causados pela ação antrópica.

Ross (1994) desenvolveu a ideia de geração de cartas de fragilidade, partindo do conceito de Análise Ecodinâmica proposto por Tricart (1977), com a finalidade de que esses conceitos pudessem ser utilizados como base para um planejamento ambiental. As unidades ecodinâmicas de instabilidade potencial têm seu grau de instabilidade em função das características físicas, como tipos de solos, declividade e pluviosidade. Já as unidades ecodinâmicas de instabilidade emergente derivam da fragilidade potencial natural e das intervenções antrópicas, ou seja, do modelo de uso da terra.

Desse modo, o conceito de fragilidade ambiental pode ser compreendido como a susceptibilidade do ambiente em sofrer qualquer tipo de dano ambiental, tanto relacionados a fatores naturais, quanto às ações (intervenções) do homem no meio ambiente, como barramentos de veios de água e uso indevido do solo (CABRAL et al., 2011).

De acordo com Spörl e Ross (2004), para uma melhor definição das diretrizes e ações a serem implementadas em um determinado espaço físico, é fundamental a identificação dos ambientes naturais e suas fragilidades emergentes e potenciais; assim sendo, a análise da fragilidade é fundamental para o zoneamento, planejamento e gestão do território.

O mapeamento da fragilidade ambiental é muito importante para o planejamento territorial em bacias hidrográficas, pois orienta o tipo de uso mais adequado em cada ambiente, visando à diminuição potencial dos impactos causados pela ocupação desordenada (OLIVEIRA et al., 2008; SILVA et al., 2008; PINESE JÚNIOR e RODRIGUES, 2012).

As bacias hidrográficas representam a melhor porção para estudos de fragilidade ambiental, uma vez que a qualidade da água da bacia reflete a sensibilidade dos impactos, pois a bacia hidrográfica é um complexo sistema ambiental, em que os cursos d'água servem, entre outros, para indicar os impactos ambientais gerados pela ação do homem ao utilizar o solo da mesma (FRANCO et al., 2012; QUEIROZ JÚNIOR et al., 2015).

Nesse sentido, a presente pesquisa teve por objetivo mapear as áreas com fragilidade ambiental da bacia hidrográfica da UHE Caçu, na perspectiva de identificar o maior ou menor grau de fragilidade dos ambientes, indicados pelo mapa de fragilidade potencial e emergente. 
A escolha da bacia da UHE Caçu como objeto de estudo deve-se à retirada da cobertura vegetal original do Cerrado, para a implantação de campos de pastagens, áreas agricultáveis, atividades sucroenergéticas e hidroelétricas, que podem gerar a compactação do solo, intensificação do escoamento superficial e aumento dos processos erosivos em áreas vulneráveis da bacia.

\subsection{Localização da área de estudo}

A bacia hidrográfica do reservatório da UHE de Caçu está localizada no trecho médio da bacia do rio Claro, no sudeste do estado de Goiás, compreendendo partes dos municípios de Caçu e Cachoeira Alta, entre as longitudes $51^{\circ} \mathrm{W}$ e $51^{\circ} 20^{\prime} \mathrm{W}$ e as latitudes $18^{\circ} 20^{\prime} \mathrm{S}$ e $18^{\circ} 40^{\prime} \mathrm{S}$ (Mapa 1). A área total da bacia hidrográfica da UHE Caçu é de 437,1 $\mathrm{km}^{2}$, sendo que, desse total, o reservatório da UHE Caçu ocupa 14,09 km² (ROCHA et al., 2015).

A UHE Caçu entrou em funcionamento no ano de 2010, operando em sistema de fio d'água, em que o nível do reservatório varia pouco. A UHE Caçu tem a capacidade instalada de $65 \mathrm{MW}$ e pertence ao grupo Gerdau Aços Longos, sendo que o reservatório da UHE Caçu tem a finalidade de gerar energia e de controlar, através da vazão de suas turbinas, o nível d'água do reservatório da UHE Barra dos Coqueiros, instalada logo abaixo no rio Claro.


Mapa 1 - Mapa de localização da Bacia Hidrográfica do Reservatório da UHE Caçu

Fonte: Organização: ROCHA, I. R. (2017). 


\section{Procedimentos Metodológicos}

Para quantificar a fragilidade ambiental da bacia hidrográfica do reservatório da UHE Caçu, foram utilizados, como base temática, os elementos declividade, tipos de solos, erosividade e uso da terra, que foram classificados segundo critérios propostos por Ross (1994), com atribuição de um código/atributo hierárquico para cada classe, relativo à sua fragilidade ambiental.

O mapa de fragilidade potencial foi elaborado a partir do cruzamento das bases temáticas solos, declividade e erosividade. O mapa de fragilidade emergente foi gerado a partir do cruzamento do mapa de uso da terra e mapa de fragilidade potencial, em que cada base é ponderada por um valor (pesos) de forma hierárquica.

Os mapas foram gerados com auxílio do programa computacional ArcGis 10.1, com base nos dados do Sistema Estadual de Geoinformação (SIEG, 2015), o qual dispõe de informações vetoriais do estado de Goiás.

Para classificação dos tipos de solo de acordo com seu grau de fragilidade ambiental, foi utilizada a proposta de Ross (1994), adaptada para os tipos de solo proposto pela EMBRAPA (2006), uma vez que a classificação de solos quanto aos critérios analisados sofreram alterações, principalmente no que tange à nomenclatura dos solos. Na bacia analisada, foram encontrados os seguintes tipos de solo: Latossolo Vermelho Distrófico, Latossolo Vermelho Distroférrico, Argissolo Vermelho Eutrófico, Argissolo Vermelho Amarelo Distrófico e Neossolo Litólico Eutrófico. A hierarquização foi feita por pesos dos tipos de solo, conforme destacado no Quadro 1.

Quadro 1- Classes de fragilidade ambiental dos tipos de solo

\begin{tabular}{|l|l|}
\hline Peso- Classe de Fragilidade Ambiental & Tipo de Solo EMBRAPA (2006) \\
\hline 1 - Muito Baixa & Latossolo Vermelho Distroférrico \\
\hline $1,5-$ Baixa & Latossolo Vermelho Distrófico \\
\hline $2-$ Média & Argissolo Vermelho Eutrófico \\
\hline $3-$ Alta & Argissolo Vermelho Amarelo Distrófico \\
\hline $5-$ Muito Alta & Neossolo Litólico Eutrófico \\
\hline
\end{tabular}

A ponderação de solos é atribuída de acordo com a fragilidade ou erodibilidade que o solo apresenta, devido à ação das águas pluviais, pelo escoamento superficial difuso e concentrado, que, segundo Ross (1994), é relativo às características físicas do solo, como textura, estrutura, plasticidade, nível de coesão das partículas e padrões dos horizontes.

As classes de declividade (Quadro 2) com os intervalos definidos em porcentagem foram geradas de acordo com a proposta de Ramalho Filho e Beek (1995), associada por graus de fragilidade.

\section{Quadro 2 - Níveis de fragilidade por classe de declividade}

\begin{tabular}{|c|c|c|}
\hline Classe de fragilidade & Declividade (\%) & Código / Atributo \\
\hline Muito Baixa & 0 a 3 & 1 \\
\hline Baixa & 3 a 8 & 2 \\
\hline Média & 8 a 20 & 3 \\
\hline Alta & 20 a 45 & 4 \\
\hline Muito Alta & $>45$ & 5 \\
\hline
\end{tabular}

Fonte: Ramalho Filho e Beek (1995). Adaptado pelos autores (2017). 
As estimativas de erosividade para a bacia foram obtidas a partir de dados pluviométricos de quatro estações da Agência Nacional das Águas (ANA), do ano de 1977 a 2014, através do sistema hidroweb (Quadro 3).

Quadro 3 - Localização das estações pluviométricas da ANA

\begin{tabular}{c|c|c|c|c|}
\hline Código da ANA & Nome da estação & Latitude & Longitude & Altitude (m) \\
\hline 1851000 & Cachoeira Alta & $18^{\circ} 54^{\prime} 34.93^{\prime \prime} \mathrm{S}$ & $50^{\circ} 51^{\prime} 1.09^{\prime \prime} \mathrm{O}$ & 500 \\
\hline 1850002 & Quirinópolis & $18^{\circ} 30^{\prime} 03.97^{\prime \prime} \mathrm{S}$ & $50^{\circ} 31^{\prime} 18.86^{\prime \prime} \mathrm{O}$ & 520 \\
\hline 1851002 & Itarumã & $18^{\circ} 45^{\prime} 53.18^{\prime \prime} \mathrm{S}$ & $51^{\circ} 20^{\prime} 49.95^{\prime \prime} \mathrm{O}$ & 480 \\
\hline 1851004 & Pombal & $18^{\circ} 45^{\prime} 47.74^{\prime \prime} \mathrm{S}$ & $51^{\circ} 49^{\prime} 31.02^{\prime \prime} \mathrm{O}$ & 650 \\
\hline
\end{tabular}

Fonte: ANA. Org.: Próprio autor (2017).

A erosividade representa a capacidade que as águas da chuva têm de erodir os solos sem cobertura vegetal. Para o cálculo de erosividade, utilizou-se a metodologia proposta por Wischmeier e Smith (1978), adaptada para as condições do Brasil por Lombardi Neto e Moldenhauer (1977), apud Bertoni e Lombardi Neto (2005), pela Equação Universal de Perda de Solos (1).

$\mathrm{EI}_{30}=67,355\left(\mathrm{r}^{2} / \mathrm{P}\right)^{85}(1)$

Onde:

$\mathrm{EI}_{30}=$ média mensal do índice de erosividade, em MJ.mm(ha.h);

$\mathrm{R}=$ médias mensais de pluviosidade em $\mathrm{mm}$;

$\mathrm{P}=$ médias anuais de pluviosidade em $\mathrm{mm}$.

O fator chuva (constante R), de acordo com Cabral et al. (2011), é o índice numérico que expressa a capacidade das precipitações pluviométricas ocasionarem erosões em um solo desprotegido. Esse potencial da chuva de causar erosão pode ser avaliado por meio de índices de erosividade, que se fundamentam nos atributos físicos das chuvas de cada região.

A avaliação da erosividade (Quadro 4) foi realizada de acordo com a proposta de Wischmeier e Smith (1978). Os resultados de erosividade são obtidos em $\mathrm{MJ} \mathrm{mm} \mathrm{ha}{ }^{-1} \mathrm{~h}^{-1} \mathrm{ano}^{-1}$ (sistema métrico internacional), sendo necessário, assim, convertê-los para o sistema métrico decimal (ton.m.mm/ha.h.ano), dividindo-os por 9,81, sendo as classes de erosividade definidas de acordo com Carvalho (2008) (Quadro 4).

Quadro 4 - Classes de erosividade da chuva por média anual

\begin{tabular}{|c|c|c|}
\hline Classes de erosividade & Erosividade (ton.m.mm/ha.h.ano) & Código / Atributo \\
\hline Muito Baixa & $\mathrm{R}<250$ & 1 \\
\hline Baixa & $250<\mathrm{R}<500$ & 2 \\
\hline Média & $500<\mathrm{R}<750$ & 3 \\
\hline Alta & $750<\mathrm{R}<1000$ & 4 \\
\hline Muito Alta & $\mathrm{R}>1000$ & 5 \\
\hline
\end{tabular}

Fonte: Adaptado de Carvalho (2008). 
Para o mapeamento do uso da terra da bacia, foram definidos dois períodos distintos: 2009, antes da formação do reservatório da UHE Caçu e 2014, após a formação do reservatório, buscando compreender se este influenciou na fragilidade dessa bacia.

Para a classificação do uso da terra da bacia antes da construção do reservatório da UHE Caçu, foi utilizada imagem do Sensor TematicMapper (TM) do satélite Landsat 5, órbita 222, ponto 73, composição colorida 5R4G3B, para 30 de junho de 2009, disponibilizada pelo Instituto de Pesquisas Espaciais - INPE (Catálogo de Imagens). Para caracterização do uso da terra após a construção do reservatório, foi utilizada imagem do satélite Landsat 8 Sensor Operational Land Imager (OLI), órbita 222, ponto 73, composição colorida 6R5G4B, data de 14 de julho de 2014 , adquirida pelo sistema Earth Explorer do US Geological Survey (USGS), gerido pela National Aeronautics and Space Administration (NASA).

Após o georreferenciamento, foi realizada a classificação não supervisionada no ArcGIS 10.1®, pela ferramenta "Multivariate/Isoclauster", que executa a agregação dos pixels semelhantes, formando as classes de uso em um arquivo matricial, o qual foi convertido em formato vetorial para melhor tratamento.

A correção dos polígonos que ficaram ambíguos foi executada através do "FildCalculator" para alteração dos atributos e reclassificação respectiva à sua classe correta, gerando o mapa temático final de uso da terra.

Para a delimitação das categorias de uso da terra, foi utilizada uma chave de interpretação para as imagens TM Landsat5, de acordo com Martins (2009), por terem as mesmas resoluções radiométricas (exceto a banda de 0,450 $0,520 \mu \mathrm{m}$, que foi gerada a partir de matemáticas de bandas do ArcGis 10.1, pela ferramenta Rastercalculator), representadas no Quadro 5, levando em consideração, especialmente, cor, textura, forma, tamanho e padrão respectivo à resposta espectral dos alvos.

Quadro 5 - Chave de interpretação para classificação de imagens de satélite

\begin{tabular}{l|l|}
\hline \multicolumn{1}{|c|}{ Classe } & \\
\hline Cerrado & $\begin{array}{l}\text { Matas ciliares e de galeria e as áreas de Cerrado mais denso, que correspondem às áreas de reserva ou } \\
\text { remanescentes. }\end{array}$ \\
\hline Pastagem & $\begin{array}{l}\text { Áreas vegetadas que apresentam cor e textura menos intensas que as áreas anteriores, interligadas a áreas } \\
\text { de pasto (pastagem sombreada). Ou ainda, áreas de grande abrangência, representadas por espaços com } \\
\text { resposta espectral em tons suaves e textura mais lisa (pastagem limpa). }\end{array}$ \\
\hline Agricultura & $\begin{array}{l}\text { Áreas de formato, na maioria das vezes, geométrico e que se encontram com vegetação em uma única } \\
\text { tonalidade, caracterizando uma cultura. }\end{array}$ \\
\hline Solo Descoberto & $\begin{array}{l}\text { Áreas sem vegetação, uma vez que a imagem foi obtida no auge do período seco na região, o que leva a } \\
\text { crer que, no período de chuvas, essas áreas destinam-se aos cultivos. }\end{array}$ \\
\hline Silvicultura & $\begin{array}{l}\text { Áreas com linhas definidas, com vegetação de médio a grande porte, plantada para obtenção de madeira } \\
\text { (Eucaliptos). }\end{array}$ \\
\hline Água & $\begin{array}{l}\text { Áreas que oferecem uma resposta espectral de tonalidades mais escuras, evidenciando a grande presença } \\
\text { de água. }\end{array}$ \\
\hline
\end{tabular}

Fonte: Martins (2009). Adaptado pelos autores (2017).

Depois de organizadas, as bases tipos de solo, declividade e erosividade foram convertidas de shapfile (.shp) para GRID, com a finalidade de elaborar o mapa de Fragilidade Potencial da bacia, através da intersecção das bases.

Para a espacialização dos dados, foi utilizado o método do interpolador Inverso do Quadrado da Distância (IQD), que, de acordo com Costa et al. (2009), se baseia na linearidade ponderada da combinação do conjunto de dados, em que o fator de ponderação é o inverso da distância. Segundo Voltz e Webster (1990), o operador pondera mais os pontos próximos das células em processamento do que aquelas mais afastadas. 
A integração das bases foi executada através do software ArcGis 10.1, pela ferramenta Combine, contida no ArcToolbox-SpatialAnalyst Tools, gerando um novo arquivo GRID, contendo todas as informações referentes aos códigos/atributos de cada classe de fragilidade das bases utilizadas. A partir desse arquivo, foi possível realizar a soma dos códigos e a média dos mesmos, por meio da opção FiedCalculator, que realiza operações algébricas, para resultar a Fragilidade Potencial da bacia hidrográfica do reservatório da UHE Caçu.

O Mapa da Fragilidade Ambiental Emergente, que pondera as características físicas associadas aos graus de proteção dos tipos de uso da terra, foi obtido através do cruzamento dos Mapas de Fragilidade Potencial e Mapa de Uso da terra (Quadro 6).

Quadro 6 - Graus de Proteção em Relação ao Uso da terra

\begin{tabular}{|l|l|}
\hline Graus de Proteção & \\
\hline 1 - Muito Alta & Florestas / Matas naturais, florestas cultivadas com biodiversidade. \\
\hline 2 - Alta & $\begin{array}{l}\text { Formações arbustivas naturais. Mata Homogênea de Pinus densa. Pastagens cultivadas com baixo pisoteio de } \\
\text { gado, cultivo de ciclo longo, como cacau. }\end{array}$ \\
\hline 3 - Média & $\begin{array}{l}\text { Cultivo de ciclo longo em curvas de nível/terraceamento como café, laranja, pastagem com baixo pisoteio, } \\
\text { silvicultura. }\end{array}$ \\
\hline 4 - Baixa & Culturas de ciclo longo de baixa densidade (café), culturas de ciclo curto. \\
\hline 5 - Muito Baixa & $\begin{array}{l}\text { Áreas desmatadas e queimadas, solo descoberto, gradeação, culturas de ciclo curto sem práticas } \\
\text { conservacionistas. }\end{array}$ \\
\hline
\end{tabular}

Fonte: Ross (1994).

A fase de confecção do Mapa da Fragilidade Emergente foram as mesmas utilizadas para confecção do Mapa da Fragilidade Ambiental Potencial, em que os dados de uso da terra foram convertidos de shapfile (.shp) para GRID e depois foi feita a intersecção dos mapas através da ferramenta Combine e realizadas as operações algébricas por meio da opção FiedCalculator.

\section{Rescultados e Discussões}

\subsection{Análise dos solos da bacia}

A bacia hidrográfica do reservatório da UHE Caçu apresenta os seguintes tipos de solo (Mapa 2): Latossolo Vermelho Distrófico, Latossolo Vermelho Distroférrico, Argissolo Vermelho Eutrófico, Argissolo Vermelho Amarelo Distrófico e Neossolo Litólico Eutrófico (Mapa 2). 


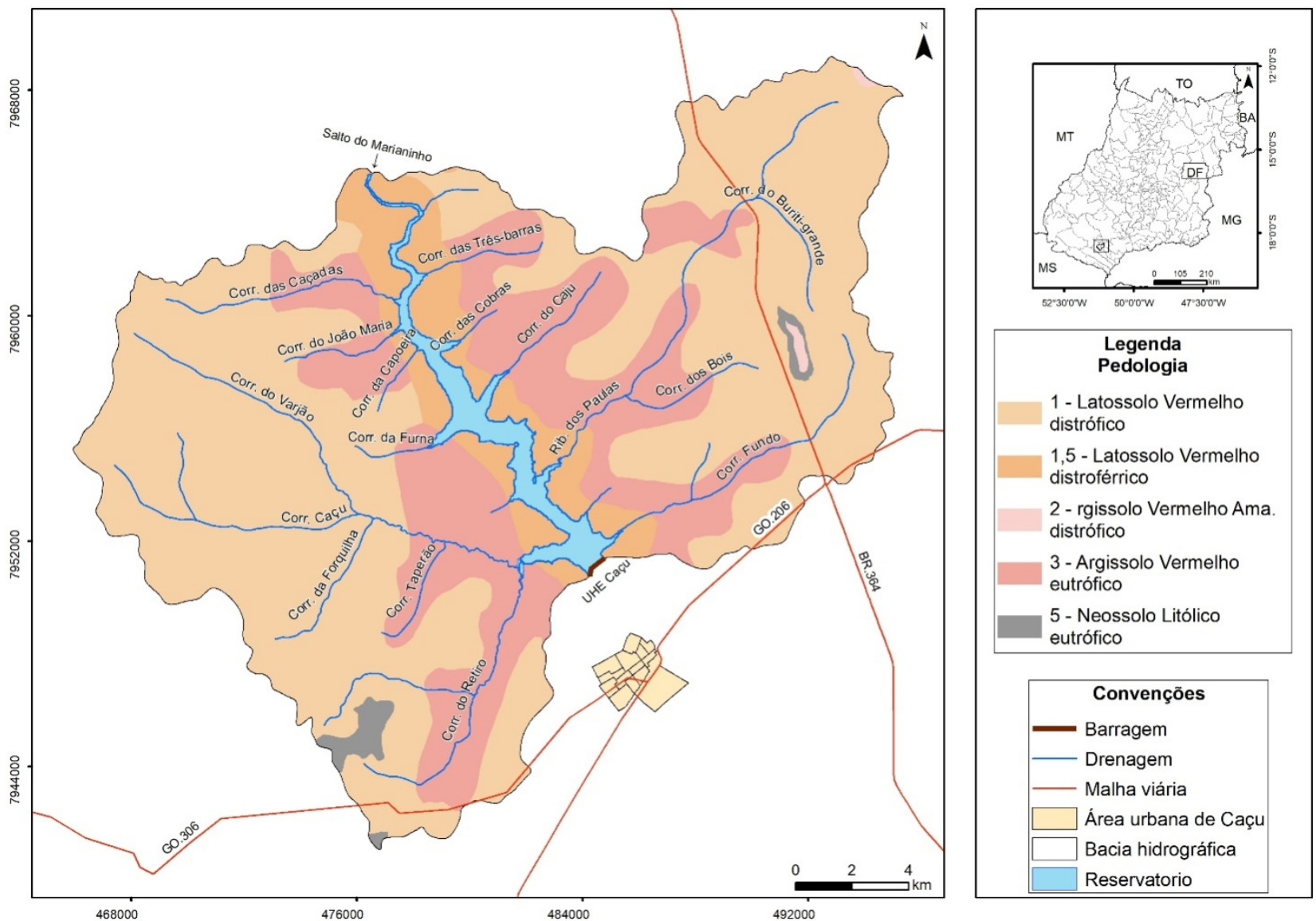

Mapa 2 - Mapa Pedológico da Bacia Hidrográfica do Reservatório da UHE Caçu Fonte: Org.: Do autor (2017).

A constituição pedológica da bacia hidrográfica do reservatório da UHE Caçu é composta, em sua maior parte, por Latossolos Vermelhos Distróficos, que ocupam $62,18 \%\left(271,8 \mathrm{~km}^{2}\right)$, enquanto que os Latossolos Vermelhos Distroférricos representam 11,33\% (49,5 km²). Esses Latossolos, segundo a Embrapa Solos (2006), caracterizam-se por serem constituídos de material mineral, serem profundos, pois o horizonte A apresenta mais de 1,5 m de espessura, bem drenados, devido aos altos teores de areia, com alto grau de intemperização e ocorrem em relevos planos e suavemente ondulados, possuindo propriedades físicas favoráveis à utilização agrícola. Segundo Valladares (2002), os horizontes Latossólicos têm uma proporção pequena de argila no horizonte $\mathrm{A}$, em que a estrutura interior do solo é composta de maciço poroso, que se desfaz em granular muito pequena.

Os Latossolos Vermelhos Distróficos têm, normalmente, frações de areias maiores que $700 \mathrm{~g} / \mathrm{kg}$, o que os tornam bastante susceptíveis à erosão, mesmo em relevos planos e suavemente ondulados, como é o caso dos Latossolos Vermelhos Distróficos encontrados na bacia analisada, que estão localizados em locais com declividade menor que $8 \%$ (VALADARES, 2002).

Os solos tipo Argissolo Vermelho Eutrófico ocupam 25,25\% $\left(110,4 \mathrm{~km}^{2}\right)$ da área da bacia, enquanto que o tipo Argissolo Vermelho Amarelo Distrófico ocupa 0,20\% $\left(0,9 \mathrm{~km}^{2}\right)$. Esses solos possuem textura que varia de arenosa a argilosa no horizonte A constituídos de material mineral, apresentando horizonte B textural e com composição de média a muito argilosa no horizonte B, sendo classificados como de média fragilidade (EMBRAPA SOLOS, 2006).

Os Neossolos Litólicos Eutróficos ocorrem sobre os relevos residuais e são solos rasos que se caracterizam pelas limitações quanto à rochosidade e pedregosidade. Nessa bacia, encontram-se em áreas de maior declividade, em área de 
formação geológica Marília, que, segundo Valadares (2002), são áreas que devem ser preservadas, sendo classificados, então, como de alta fragilidade. Ocupavam $1,05 \%\left(4,6 \mathrm{~km}^{2}\right)$ da bacia.

\subsection{Avaliação da declividade}

A declividade é uma das principais variáveis quanto ao mapeamento de fragilidade ambiental, pois os processos erosivos hídricos, associados a outros fatores, podem ser acelerados a partir do grau de inclinação da vertente do terreno.

O mapa de declividade definido em intervalos de porcentagem mostra que, na bacia, predominam áreas com baixa declividade, destacando-se, em sua maioria, áreas com declividades que variam de 0 a 8\% (Mapa 3) e ocupam 92\% da área, sendo classificado entre relevo plano a suavemente ondulado.

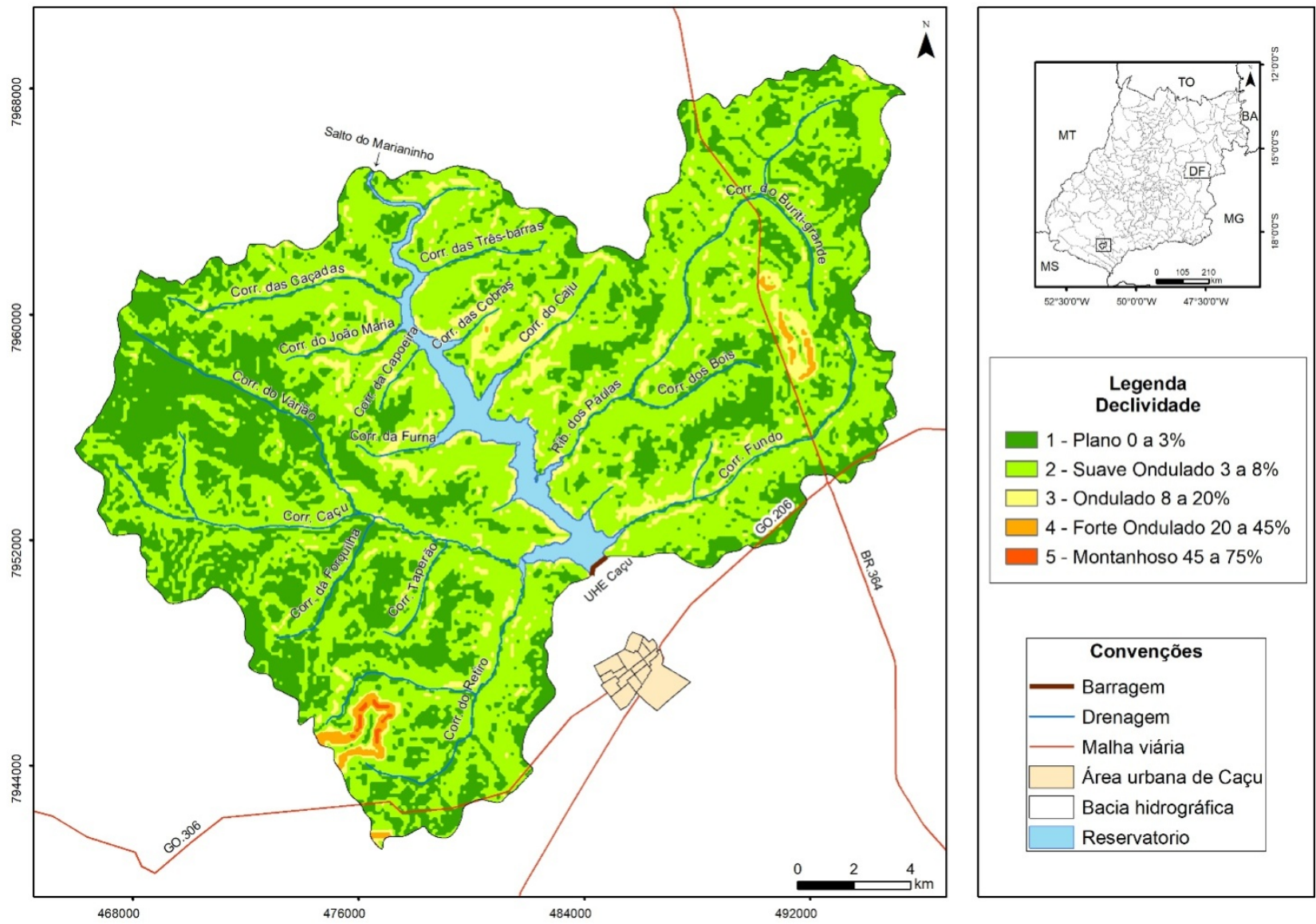

Mapa 3 - Mapa de Declividade da Bacia Hidrográfica do Reservatório da UHE Caçu Fonte: Org.: Do autor (2017).

As áreas de $0 \%$ a $3 \%$ foram classificadas como de muito baixa fragilidade; já as áreas de $3 \%$ a $8 \%$ foram classificadas como de baixa fragilidade, ou seja, a bacia apresenta, de modo geral, baixo potencial de fragilidade ambiental em relação à declividade.

Em termos gerais, tanto na margem direita como na margem esquerda do reservatório, localizam-se áreas com declividade entre $8 \%$ a $20 \%$ que merecem maiores cuidados, pois, geralmente, são utilizadas e estão aptas para agricultura moderna, desde que se empreguem técnicas adequadas de manejo e conservação do solo. 
As áreas classificadas como de alto potencialde fragilidade, foram detectadas no Morro do Mauro, na margem direita da bacia e Morro Estancia JC na margem esquerda, onde a declividade é superior a 20\% e ocorre o predomínio de rochas de FormaçãoVale do Rio do Peixe e Formação Marília. Conforme Fernandes (2004) e Cabral et al (2009), a Formação Vale do Rio do Peixe é constituída por arenitos intercalados com siltitos ou lamitos arenosos. Os arenitos são muito finos a finos, de cor marrom claro, rosados a alaranjados, de seleção moderada a boa, portanto a apresentar menor resistência à erosão em relação às rochas da Formação Marília, que é constituída por arenitos com frequente cimentação carbonática, característica que os torna mais resistentes à erosão quando menos intemperizados.

\subsection{Erosividade}

Os valores de erosividade foram gerados a partir de dados provenientes dos postos pluviométricos, obtidos de quatro estações pluviométricas da ANA na região para bacia hidrográfica do reservatório da UHE Caçu, entre os anos de 1977 a 2014

Observaram-se índices pluviométricos médios aproximados de $1480 \mathrm{~mm}$ anuais entre os anos de 1977 e 2009 , e de 2010 a 2014 a média foi de $1420 \mathrm{~mm}$, sendo que entre os meses de outubro a abril ocorrem entre 85\% a 90\% precipitação anual. A erosividade é uma variável diretamente proporcional aos índices pluviométricos, e terá uma maior perda de solos no período chuvoso, meses em que se obteve médias mensais superiores a $80 \mathrm{~mm}$.

$\mathrm{Na}$ avaliação da erosividade da bacia, foram adotadas 5 classes, porém, os resultados obtidos a partir da metodologia, enquadraram toda área da mesma em uma única classe, com índices variando em torno de $810,36 \mathrm{t} \mathrm{mm}^{\mathrm{n}}$ ${ }^{1}$ ano $^{-1}$ (Mapa 4), valor considerado como classe de erosividade Alta, conforme metodologia desenvolvida por Carvalho (2008), segundo a qual a erosividade do solo é considerada alta quando varia de 750 a $1000 \mathrm{t} \mathrm{mm} \mathrm{ha}^{-1} \mathrm{ano}^{-1}$. Silva (2008), Cabral et al. (2011), Rocha e Cabral (2011) encontraram resultados semelhantes, ou seja, áreas com classes de erosividade alta, em áreas próximas à bacia analisada.

\subsection{Fragilidade Potencial}

O mapeamento da fragilidade potencial de uma bacia hidrográfica é importante no que se refere ao entendimento do potencial à erodibilidade do solo da bacia, de acordo com suas características físicas em relação aos aspectos climáticos. O mapa da fragilidade potencial (Mapa 5) da bacia foi gerado a partir do cruzamento das classes de solo, declividade e erosividade.

De acordo com o mapa de fragilidade potencial da bacia hidrográfica do reservatório da UHE Caçu, 69,65 \% da área da bacia têm fragilidade potencial classificada como baixa. A baixa fragilidade potencial observada em grande parte da bacia analisada ocorreu em áreas de Latossolos e Argissolos, que são os tipos de solos predominantes na bacia, e em áreas com declividade entre $0 \%$ a $8 \%$. Fato semelhante às classes detectadas para a bacia da UHE Caçu foram constatados por Melo et al. (2014), no estudo de fragilidade ambiental dos solos no Estado do Paraná, uma vez que os Latossolos e os Argissolos são solos de baixa erodibilidade e bastantes permeáveis (SOARES et al., 2011; RIBEIRO et al., 2016).

As áreas classificadas como de média fragilidade potencial representam 29,24\% da bacia e estão localizadas em áreas com declividade variando de 8 a $20 \%$, e em áreas de Argissolo Vermelho Eutrófico. As áreas que foram classificadas como de alta fragilidade potencial representam 1,04\% da área da bacia e localizam-se em áreas de Neossolos Litólicos Eutrófico e Argissolo Vermelho Amarelo Distrófico, solos estes mais susceptíveis à erosão. 

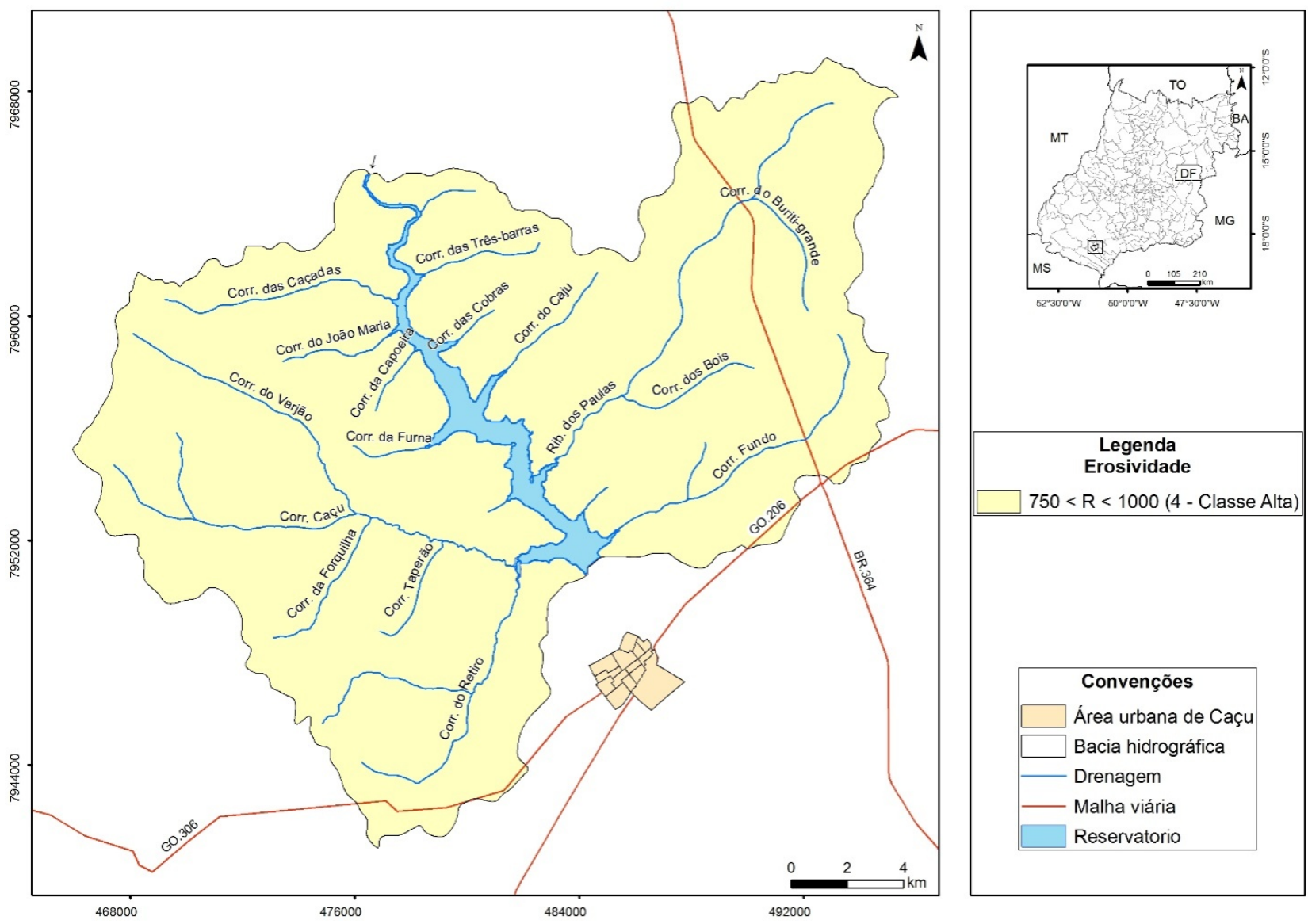

Mapa 4 - Mapa de Erosividade da Bacia Hidrográfica do Reservatório da UHE Caçu Fonte: Org.: Próprio autor (2017).

Já as áreas classificadas como de muito alta fragilidade potencial ocupam 0,07\% da área da bacia. Estão localizadas em áreas de encosta de morros, em que o solo predominante é Neossolo Litólico Eutrófico e a declividade esta acima de $20 \%$.

De acordo com o mapa de fragilidade potencial da bacia hidrográfica do reservatório da UHE Caçu, 69,65 \% da área da bacia têm fragilidade potencial classificada como baixa. A baixa fragilidade potencial observada em grande parte da bacia analisada ocorreu em áreas de Latossolos e Argissolos, que são os tipos de solos predominantes na bacia, e em áreas com declividade entre $0 \%$ a $8 \%$. Fato semelhante às classes detectadas para a bacia da UHE Caçu foram constatados por Melo et al. (2014), no estudo de fragilidade ambiental dos solos no Estado do Paraná, uma vez que os Latossolos e os Argissolos são solos de baixa erodibilidade e bastantes permeáveis (SOARES et al., 2011; RIBEIRO et al., 2016).

As áreas classificadas como de média fragilidade potencial representam 29,24\% da bacia e estão localizadas em áreas com declividade variando de 8 a $20 \%$, e em áreas de Argissolo Vermelho Eutrófico. As áreas que foram classificadas como de alta fragilidade potencial representam 1,04\% da área da bacia e localizam-se em áreas de Neossolos Litólicos Eutrófico e Argissolo Vermelho Amarelo Distrófico, solos estes mais susceptíveis à erosão.

Já as áreas classificadas como de muito alta fragilidade potencial ocupam 0,07\% da área da bacia. Estão localizadas em áreas de encosta de morros, em que o solo predominante é Neossolo Litólico Eutrófico e a declividade esta acima de $20 \%$. 

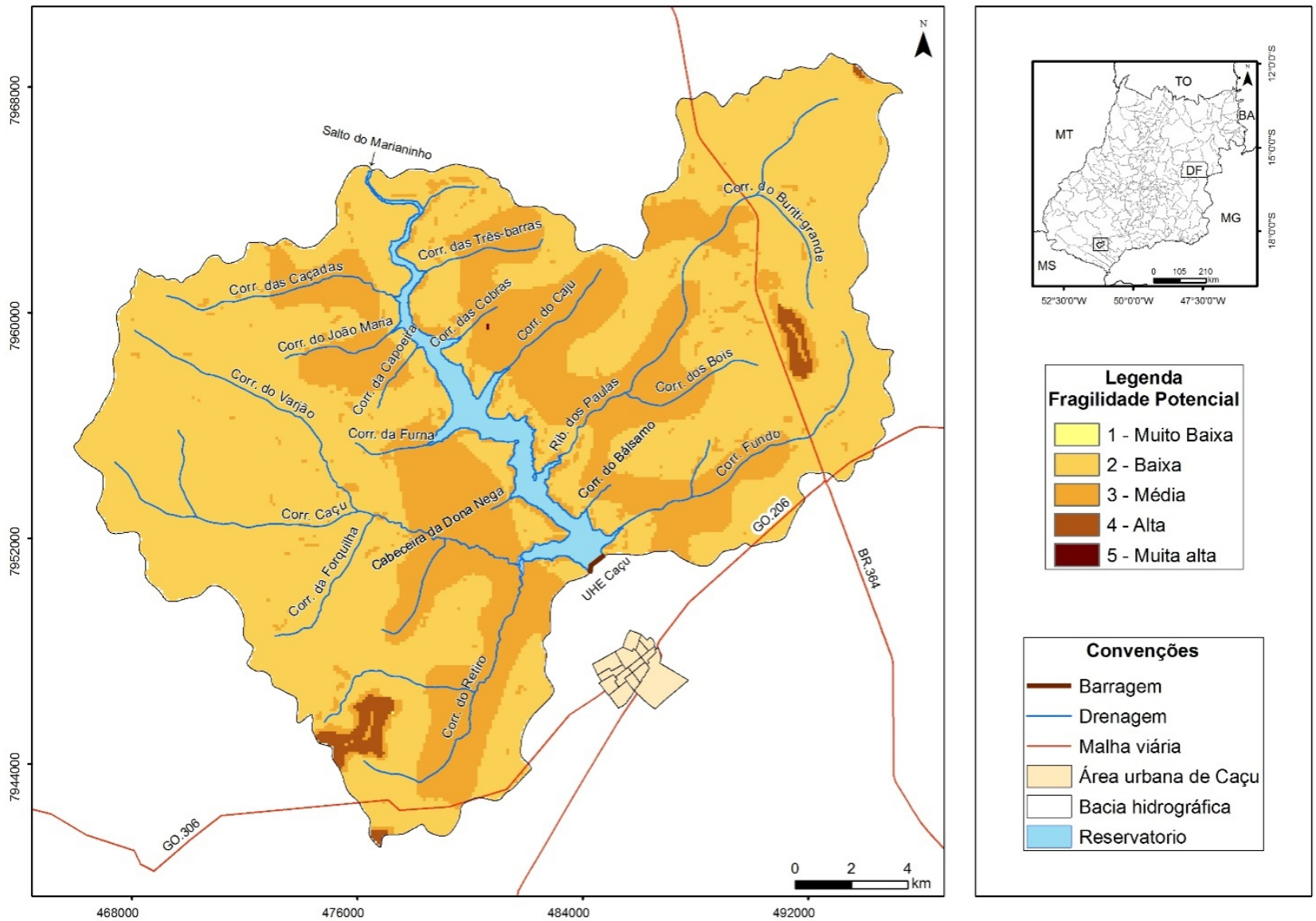

Mapa 5 - Mapa de Fragilidade Potencial da Bacia Hidrográfica do Reservatório da UHE Caçu Fonte: Org.: Próprio autor (2017).

Na bacia hidrográfica em análise, destaca-se o uso do solo como pastagem para gado de leite e de corte, sendo que, em 2009, a pastagem ocupava $71,91 \%$ da área da bacia, aumentando, em 2014, aproximadamente, $3 \mathrm{~km}^{2}$ da área de pastagem, totalizando $72,67 \%$ da área, ocupando áreas que estavam com solo descoberto em 2009 e preparando-as para o plantio de pastagem ou ainda áreas remanescestes de Cerrado.

As áreas de Cerrado ou matas ciliares remanescentes da vegetação natural da bacia, em 2009, ocupavam 22,20 \% da área; em 2014, ocupavam 21,57 \%. Isso se deu devido ao fato de as áreas de matas ciliares, ao longo das margens do rio Claro e seus afluentes, serem inundadas pela formação do lago do reservatório.

As áreas submersas por águas ocupavam 0,67\% da área da bacia em 2009 e 3,19\% em 2014. O aumento da área submersa foi proporcionado pela formação do reservatório.

As áreas ocupadas por culturas apresentaram um aumento no período analisado; ocupavam $0,60 \% \mathrm{em} 2009 \mathrm{e}$ aumentou para 1,26\% em 2014. Tal fato pode ser associado às lavouras de cana-de-açúcar, devido à instalação de usinas de etanol na região. As áreas ocupadas com silviculturas ocupavam 0,19\% da área da bacia em 2009 e 0,79\% em 2014 .

\subsection{Fragilidade Emergente}

Os mapas da fragilidade emergente (2009 e 2014) da bacia hidrográfica do reservatório da UHE Caçu foram gerados a partir do cruzamento do mapa de fragilidade potencial e mapa de uso da terra da bacia, referentes aos anos de 2009 e 2014 (Mapas 8 e 9). 


\subsection{Análises do modelo de uso da terra}

No mapeamento do uso da terra da bacia, foram considerados dois períodos distintos, sendo o primeiro referente ao ano de 2009, que corresponde ao período antes da formação do reservatório da UHE Caçu (Mapa 6), e o segundo referente a 2014, correspondente a fase após a construção do reservatório (Mapa 7).
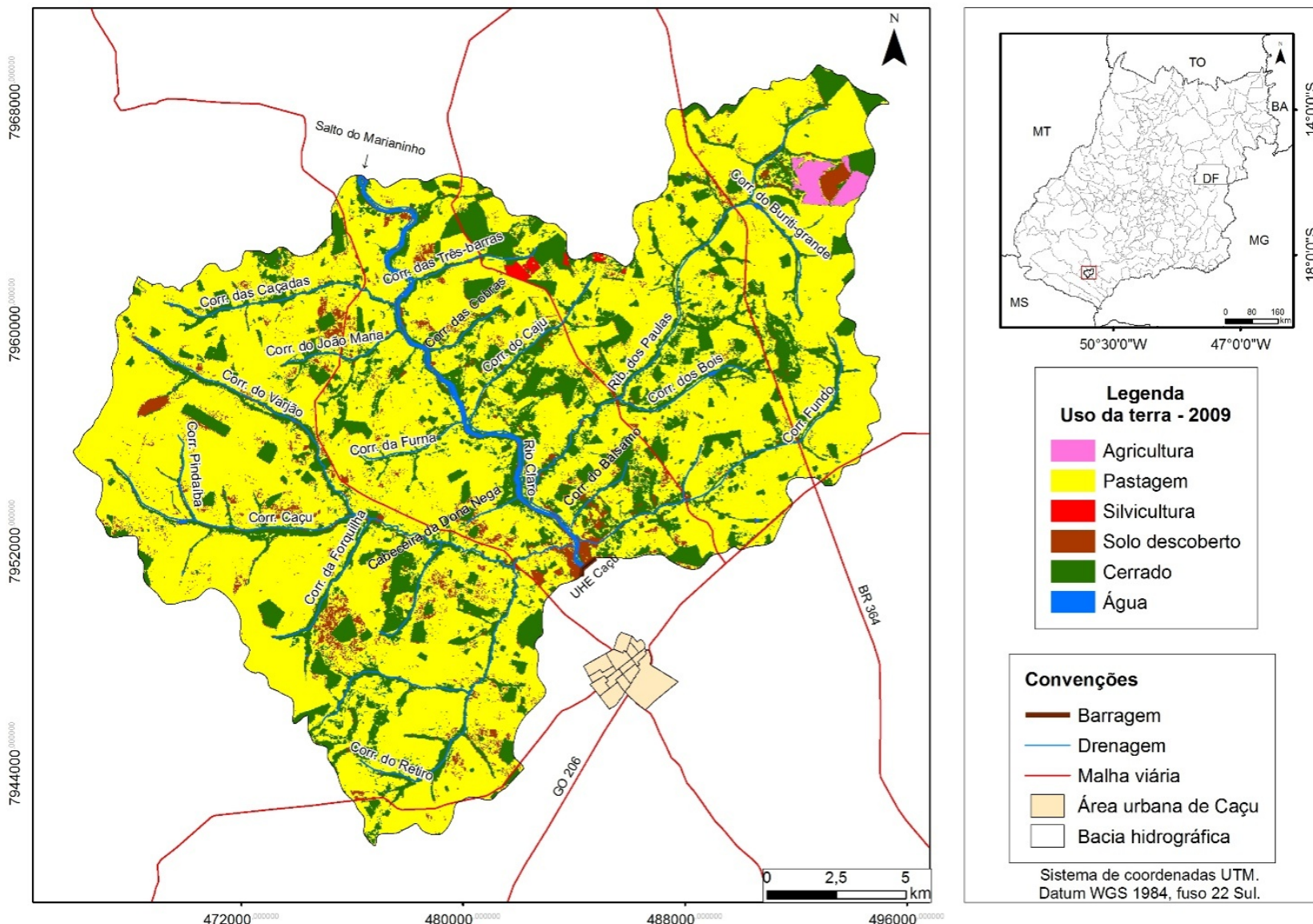

Mapa 6 - Mapa de uso da terra da Bacia Hidrográfica do Reservatório da UHE Caçu em 2009 Fonte: Org.: Próprio autor (2017).

As áreas de fragilidade emergente de 2009 e 2014 são parecidas com as áreas de fragilidade potencial, porém, com algumas mudanças e justificativas: as áreas de baixa fragilidade emergente, em 2009, ocupavam 74,88\% da área da bacia, e em 2014 ocupavam 77,52\% da área. Esse aumento pode ser associado ao modelo de uso da terra, pois áreas que foram classificadas como solo descoberto devido à retirada da vegetação para formação do reservatório em 2009, em 2014 passou a ser área submersa, mudando, assim, de alta fragilidade em 2009 para baixa fragilidade em 2014.

As áreas de fragilidade emergente classificadas como baixa na bacia, estão localizadas em áreas de Latossolo Vermelho, com declividade variando de 0 a $8 \%$. Os Latossolos são considerados solos de menor granulometria, mais compactos e de difícil desagregação com a ação das chuvas, favorecendo as baixas fragilidades potencial e emergente, pois apresentam grande resistência e estabilidade quanto à erosão (AYER et al., 2015). Entretanto, os Latossolos constituem a classe de solo de maior utilização na agricultura no Brasil, mas, a falta de prática e de técnicas conservacionistas, causa sérios impactos ambientais, como compactação do solo, carreamento de sedimentos por erosão laminar, assoreamento de rios e lagos, prejudicando e até comprometendo a qualidade e quantidade de água potável com defensivos agrícolas e adubos (NASCIMENTO et al., 2016). 

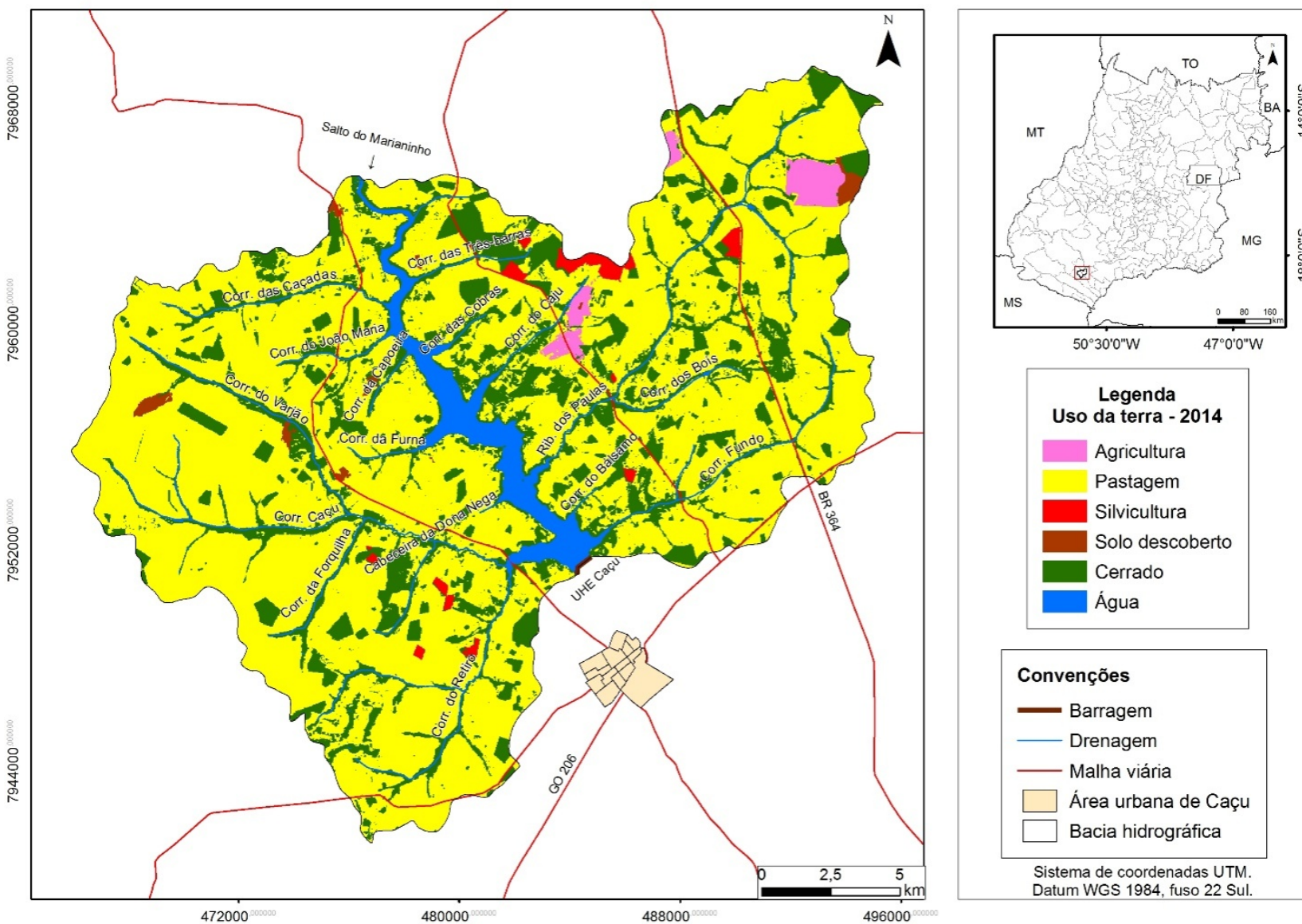

\section{Convenções}

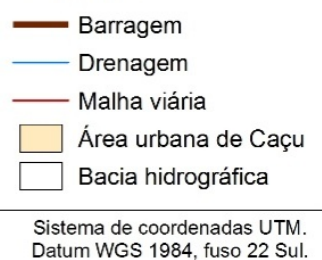

Mapa 7 - Mapa de uso da terra da Bacia Hidrográfica do Reservatório da UHE Caçu em 2014

Fonte: Org.: Próprio autor (2017).

As áreas de fragilidade média, que representavam 20,79\% em 2009, passaram a representar 21,12\% da área da bacia. Esse fato deu-se, principalmente, em razão do aumento da área ocupada por pastagem em 2009 e 2014 , que aumentou em $0,70 \%$ da área da bacia no período analisado. Nessas áreas, nos dois períodos analisados, destacam-se as áreas de Argissolo Vermelho Amarelo Distrófico, cujo uso principal compõe-se de pastagens. Resultado semelhante foi encontrado por Pinese Júnior e Rodrigues (2012) na determinação da vulnerabilidade ambiental da bacia hidrográfica do Rio Piedade (MG), em que foi destacado que áreas de pastagens favorecem a maior vulnerabilidade ao solo frente aos efeitos da erosão, pois as pastagens reduzem a infiltração do solo, propiciando o escoamento superficial.

Já a classe de alta fragilidade emergente, em 2009, ocupava 4,34\% da bacia, e em 2014 passou a ocupar 1,36\% da área. Tal fato justifica-se devido à área que ficou submersa, principalmente nas proximidades da barragem da UHE Caçu, que em 2009 estava com solo descoberto devido à retirada da vegetação para formação do reservatório, que foi classificada como de alta fragilidade, e em 2014 passou a ser área submersa, passando a ser área de baixa fragilidade em 2014.

$\mathrm{Na}$ bacia analisada, áreas de Neossolos, que estão nas encostas de morros residuais, com declividades acima de $20 \%$, foram classificadas como de fragilidade potencial muito alta e representavam $0,07 \%$ da área da bacia; com o cruzamento do uso da terra nos períodos analisados, em que foi observado a preservação da vegetação natural nestas áreas de encostas, e consequentemente ás levou a classificar como áreas de alta fragilidade emergente. Segundo Tricart (1977) e Melo et al. (2014), a cobertura vegetal é um dos principais - senão o mais relevante - fatores de proteção e estabilidade dos processos morfodinâmicos do solo, tendo capacidade de frear as ações de degradação do solo. Assim, a 


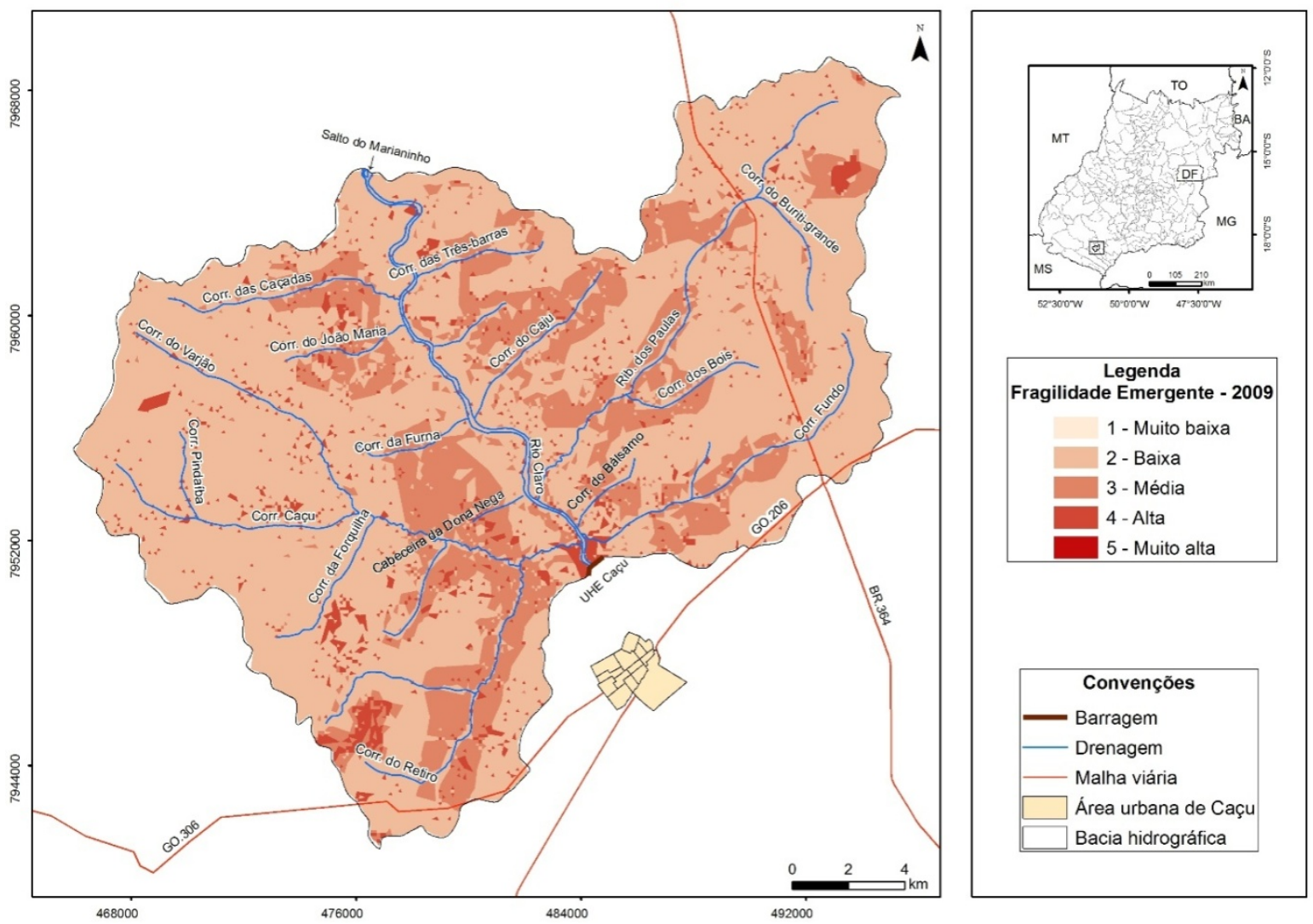

Mapa 8 - Mapa de Fragilidade Emergente da Bacia Hidrográfica do Reservatório da UHE Caçu em 2009

Fonte: Org.: Próprio autor (2017).

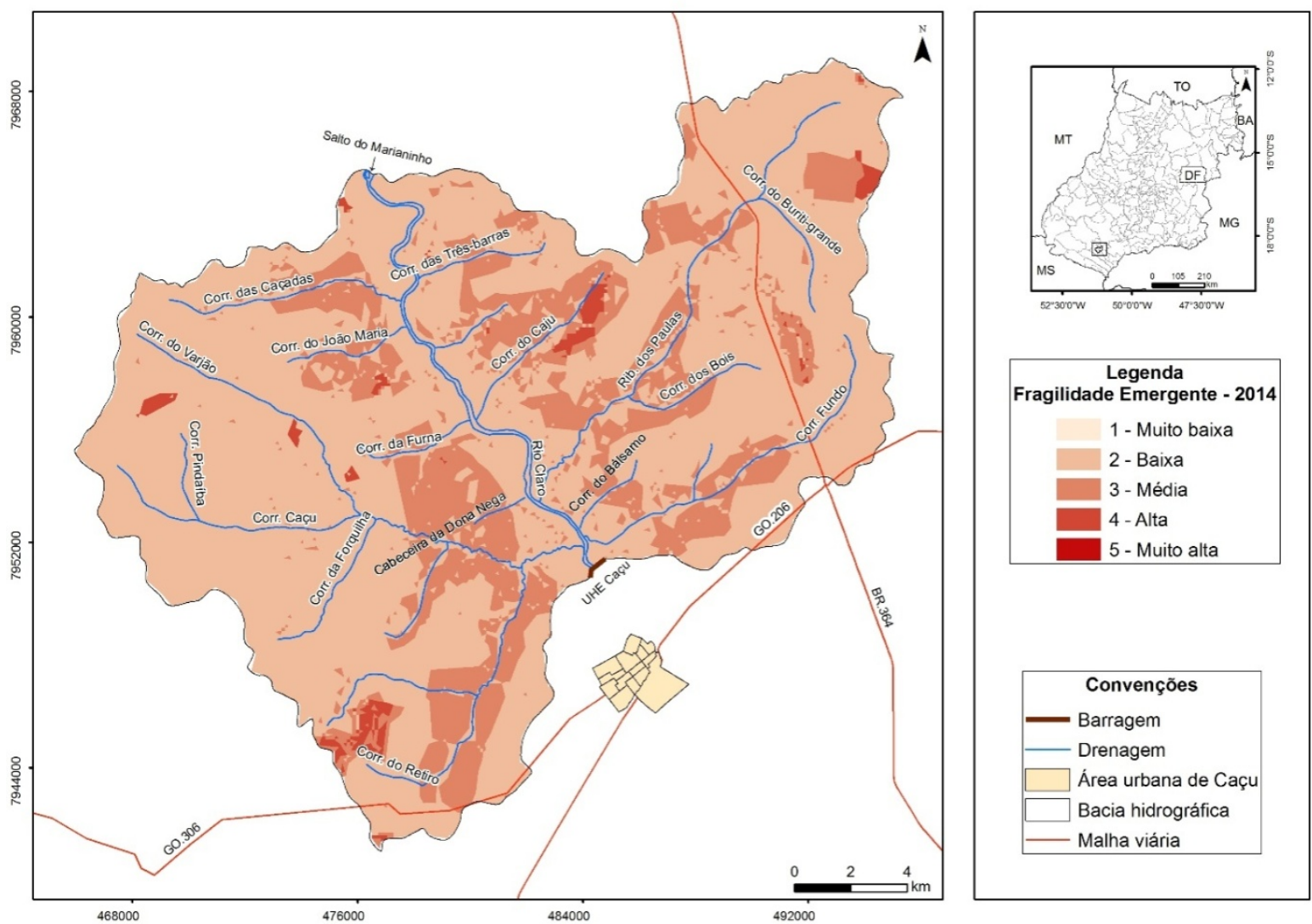

Mapa 9 - Mapa de Fragilidade Emergente da Bacia Hidrográfica do Reservatório da UHE Caçu em 2014 Fonte: Org.: Próprio autor (2017). 
presença ou ausência de cobertura vegetal alteram, em muito, a conformação das classes de vulnerabilidade do solo.

O principal diferencial entre os mapas de fragilidade potencial e fragilidade emergentes, nos dois períodos avaliados, são as áreas da bacia com solo descoberto ou solos ocupados com culturas anuais, pois a exposição do solo sem cobertura vegetal propicia a degradação do mesmo por processo de erosão laminar. Resultado semelhante foi encontrado por Pinese Júnior e Rodrigues (2012) na determinação da fragilidade ambiental da bacia hidrográfica do Rio Piedade (MG), em que áreas com solos expostos ou preparados para o plantio mostraram-se mais favoráveis à fragilidade do ambiente.

\section{Conclusões}

O estudo da fragilidade ambiental em bacias hidrográficas é muito importante para nortear as políticas de gestão e monitoramento da bacia quanto ao planejamento do uso da terra, objetivando o melhor desenvolvimento econômico com vistas à preservação do meio ambiente.

O predomínio da classe baixa fragilidade emergente na bacia analisada, ocorre em virtude do relevo ser pouco ondulado, variando, principalmente, entre as classes de 0 a $3 \%$ ou de 3 a $8 \%$ de declividade, com a predominância de Latossolos Vermelhos, que, em geral, são solos profundos, bem drenados e com altos teores de areias, e ainda de essas áreas terem cobertura natural permanentes, sejam áreas de Cerrado natural ou pastagens permanentes.

A maior parte das áreas com fragilidade potencial e fragilidade emergente, classificadas como média fragilidade ambiental, localiza-se em áreas de Argissolo e se encontram em áreas com declive entre 8 e 20\%.

Os resultados encontrados na pesquisa mostram que, em 2009, 74,88 \% da bacia destacavam-se como de baixa fragilidade ambiental, aumentando, em 2014, para $77,52 \%$. As áreas de média fragilidade passaram de $20,79 \%$, em 2009, para 21,12\%, em 2014, enquanto que as áreas de alta fragilidade diminuíram de 4,34\%, em 2009, para 1,36\% em 2014, devido às mudanças no uso do solo da bacia.

É fundamental destacarmos que aproximadamente $25 \%$ da área da bacia classificam-se entre média e alta fragilidade, demostrando a necessidade de cuidados especiais e utilização de práticas conservacionista em relação ao uso da terra, principalmente nessas áreas.

\section{Agradecimentos}

Ao Instituto Federal de Goiás pela licença de capacitação que deu condição à realização desta pesquisa.

A Fundação de Amparo à Pesquisa do Estado de Goiáspela bolsa de formação que colaborou financeiramente para realização desta pesquisa.

À capes e ao Programa de Cooperação Acadêmica, pelo financiamento de parte da pesquisa através do Processo 88887.124105/2014-00. Projeto "Análise integrada em bacias hidrográficas: estudos comparativos com distintos uso e ocupação do solo". 


\section{Referências}

ANA - Agência Nacional das Águas. Sistema Nacional de Informações sobre Recursos Hídricos (SNIRH) - Estações da ANA. Available from: http://www.ana.gov.br/PortalSuporte/frmSelecaoEstacao.aspx.

AYER JEB, OLIVETTI D, MINCANTO RL, SILVA MLN. Erosão hídrica em Latossolos Vermelhos Distróficos. Pesquisa Agropecuária Tropical. Goiânia, v. 45, n. 2, p. 180 - 191, abr. / jun. 2015. Availablefrom:https://www.revistas.ufg.br/pat/article/view/31197/18630.

BERTONI JC, LOMBARDI NETO J. Conservação do solo. 5. ed. São Paulo: Ícone, 2005.

BRADY NC, WEIL RR. Elementos da natureza e propriedades dos solos. Porto Alegre: Bookman, 2013.

CABRAL JBP, FERNANDES LA, BECEGATO V A, DA SILVA S A. Erosividade na bacia de drenagem do reservatório de Cachoeira Dourada - Go/MG. Geofocus (Artículos), n.9, p. 290-316, 2009.

CABRAL JBP, ROCHA IR, MARTINS AP, ASSUNÇÃO HF, BECEGATO VA. Mapeamento da fragilidade ambiental da bacia hidrográfica do Rio Doce (GO), utilizando técnicas de geoprocessamento. GeoFocus (Artículos), n. 11, p.51-69,2011.

CARVALHO NO. Hidrossedimentologia prática. 2. ed., rev., atual. e ampliada. Rio de Janeiro: Interciência, 2008.

COSTA FHS, SOUZA FILHO CR, RISSO A. Modelagem espaço-temporal da erosão e potencial contaminação de Arsênio e Chumbo na bacia hidrográfica do rio Ribeira de Iguape (SP). Revista Brasileira de Geociências, São Paulo, v. 39, n. 2, p. 338-349,jun., 2009. Availablefrom: http://www.dcs.ufla.br/site/_adm/upload/file/pdf/Prof\%20Marx/Aula $\% 205 /$ Outro\%20art\%20interesse/Costa\%20et\%20al_EUPS_As_Pb.pdf.

EMBRAPA - Empresa Brasileira de Pesquisa Agropecuária, Sistema Brasileiro de Classificação de Solos.Editores Técnicos, Humberto Gonçalves dos Santos et al. Rio de Janeiro: Embrapa Solos, 2006. Availablefrom:https://www.agrolink.com.br/downloads/sistema-brasileiro-de-classificacao-dos-solos2006.pdf.

EMBRAPA - Empresa Brasileira de Pesquisa Agropecuária. Brasil em Relevo, Monitoramento por Satélite, 2006. Availablefrom:http://www.relevobr.cnpm.embrapa.br/index.htm.

EnvironmentalSystemsResearchInstitute. Software ArcGisMap 10.1, sob Licença de número: EFL913687012, do Laboratório de Geoinformação da Universidade Federal de Goiás - Câmpus Jataí.

FERNANDES LA. Mapa litoestratigráfico da parte oriental da bacia Bauru (PR, SP, MG), escala 1:1.000.000. Boletim Paranaense de Geociências, 55, p.53-66,2004.

FRANCO GB, BETIM LS, MARQUES EAG, GOMES RL, CHAGAS CS. Relação qualidade da água e fragilidade ambiental da Bacia do Rio Almada, Bahia. Revista Brasileira de Geociências. Edição 42 (Suppl 1), p.114-127, dez. 2012. Availablefrom: file:///C:/Users/ccarv/Downloads/Relacao-qualidade-da-agua-e-fragilidade-ambiental-da-Baciado-Rio-Almada.pdf.

QUEIROZ JUNIOR VS, CABRAL JBP, DA ROCHA IR, BARCELOS AA.N. Uso de geotecnologias na caracterização da fragilidade ambiental da Bacia da UHE Foz do Rio Claro (GO), GeoFocus,2015:n ${ }^{\circ}$ 15, p. 193212.Availablefrom:http://www.geofocus.org/index.php/geofocus/article/view/413.

MARTINS AP. Bacia do Ribeirão Cachoeira de Cima, Itapagipe (MG): Avaliação ambiental integrada a alternativas de uso. Dissertação de Mestrado (Geografia), Instituto de Geografia da Universidade Federal de Uberlândia. Uberlândia, Minas Gerais (2009).

MELO LC, SANQUETTA CR, HENTZ AMK, CORTE APD. Análise da fragilidade ambiental potencial dos solos do Paraná. Revista do Departamento de Geografia - USP, v. 28, p. 101-111,2014. 
NASCIMENTO NS, VIEIRA EM, GONÇALVES JAC, CUNHA GDEPQ. Estudo da vulnerabilidade ambiental em uma microbacia hidrográfica empregando hierarquia nominal e operador local. Revista Brasileira de Geografia Física, v. 09, n. 03, p. 897-916, 2016.

OLIVEIRA PCA, RODRIGUES GSSC, RODRIGUES SC. Fragilidade ambiental e uso do solo da Bacia Hidrográfica do Córrego Pindaíba, Uberlândia, MG, Brasil. Revista Ambiente e Água, Taubaté, v. 3, n. 1, p. 54-67, 2008.

PINESE JUNIOR JF, RODRIGUES SC. O Método de Análise Hierárquica - AHP - Como auxílio na determinação da vulnerabilidade ambiental da Bacia Hidrográfica do Rio Piedade (MG). Revista do Departamento de Geografia - USP, v. 23, p. 4-26, 2012.

RAMALHO FILHO A, BEEK KL. Sistema de avaliação da aptidão agrícola das terras. 3. ed., rev. Rio de Janeiro: EMBRAPA - CNPS, 1995.

RIBEIRO AS, MINCATO RL, CURI N, KAWAKUBO FS. Vulnerabilidade ambiental à erosão hídrica em uma subbacia hidrográfica pelo processo analítico hierárquico. Revista Brasileira de Geografia Física, v. 09, n. 01, p. 16-31, 2016.

ROCHA IR, CABRAL JBP. Uso de técnicas de sensoriamento remoto e geoprocessamento na análise da fragilidade ambiental da Bacia Hidrográfica da UHE Barra dos Coqueiros - GO. In: XIX SEMINÁRIO DE INICIAÇÃO CIENTÍFICA / VIII COMPEX, 2011, Goiânia. Anais...Universidade Federal de Goiás. Goiânia, GO, 2011.

ROCHA IR, CABRAL JBP, NOGUEIRA PF, BARCELOS AA. Avaliação sazonal das águas do reservatório da usina hidrelétrica Caçu no Município de Caçu, Goiás. Revista do Departamento de Geografia - USP, v. 29, p. 137-160, 2015.

ROSS JLS. Análise empírica da fragilidade dos ambientes naturais e antropizados. Revista do Departamento de Geografia - FFLCH - USP, São Paulo, n. 8,p. 63-74, 1994.

SIEG. Sistema Estadual de Geoinformação de Goiás, 2015. Availablefrom: http://www.sieg.go.gov.br.

SILVA ICO, CABRAL JBP, SCOPEL I. Mapeamento da Fragilidade Ambiental da Bacia Hidrográfica do Córrego da Onça em Jataí (GO), Utilizando Técnicas de Geoprocessamento. Revista Eletrônica Geoambiente On-Line - UFG. JataíGO, $\quad$ n. $11, \quad$ jul.-dez., $\quad 2008 . \quad$ p. $\quad 242-270$. http://www.revistas.ufg.br/index.php/geoambiente/article/view/25976/14945.

SOARES MRGJ, SOUZA JLM, JERSZURKI D. Fragilidade ambiental da bacia do rio Pequeno em São José dos Pinhais (PR). Revista Geografia (Londrina), v. 20, n. 3, p. 057-070, set / dez 2011. Availablefrom: http://www.moretti.agrarias.ufpr.br/publicacoes/tc_2011_geografia_1.pdf.

SPÖRL C. Metodologia para elaboração de modelos de fragilidade ambiental utilizando redes neurais. 185 f. 2007. Tese (Doutorado em Geografia) - Programa de Pós-Graduação em Geografia. Universidade de São Paulo. São Paulo, 2007.

SPÖRL C, ROSS JLS. Análise comparativa da fragilidade ambiental com aplicação de três modelos. GEOUSP Espaço e Tempo, São Paulo, n. 15, p. 39-49, 2004.

TRICART J. Ecodinâmica. Rio de Janeiro: SUPREN/IBGE, 1977.

VALLADARES GS. Caracterização dos solos e classes de terra para irrigação do Oeste da Bahia. Campinas: EmbrapaMonitoramentoporSatélite, 2002.

VOLTZ M, WEBSTER R. A comparison of kriging, cubic splines and classification for predicting soil properties from sample information. J. Soil Sci., v. 41, p. 473-490,1990.

WISCHMEIER WH, SMITH DD. Predicting rainfall erosion losses: a guide to conservation planning. Washington, United States Department of Agriculture, p. 58. (Agriculture Handbook, 537), 1978. 